\title{
Gultura이요
}

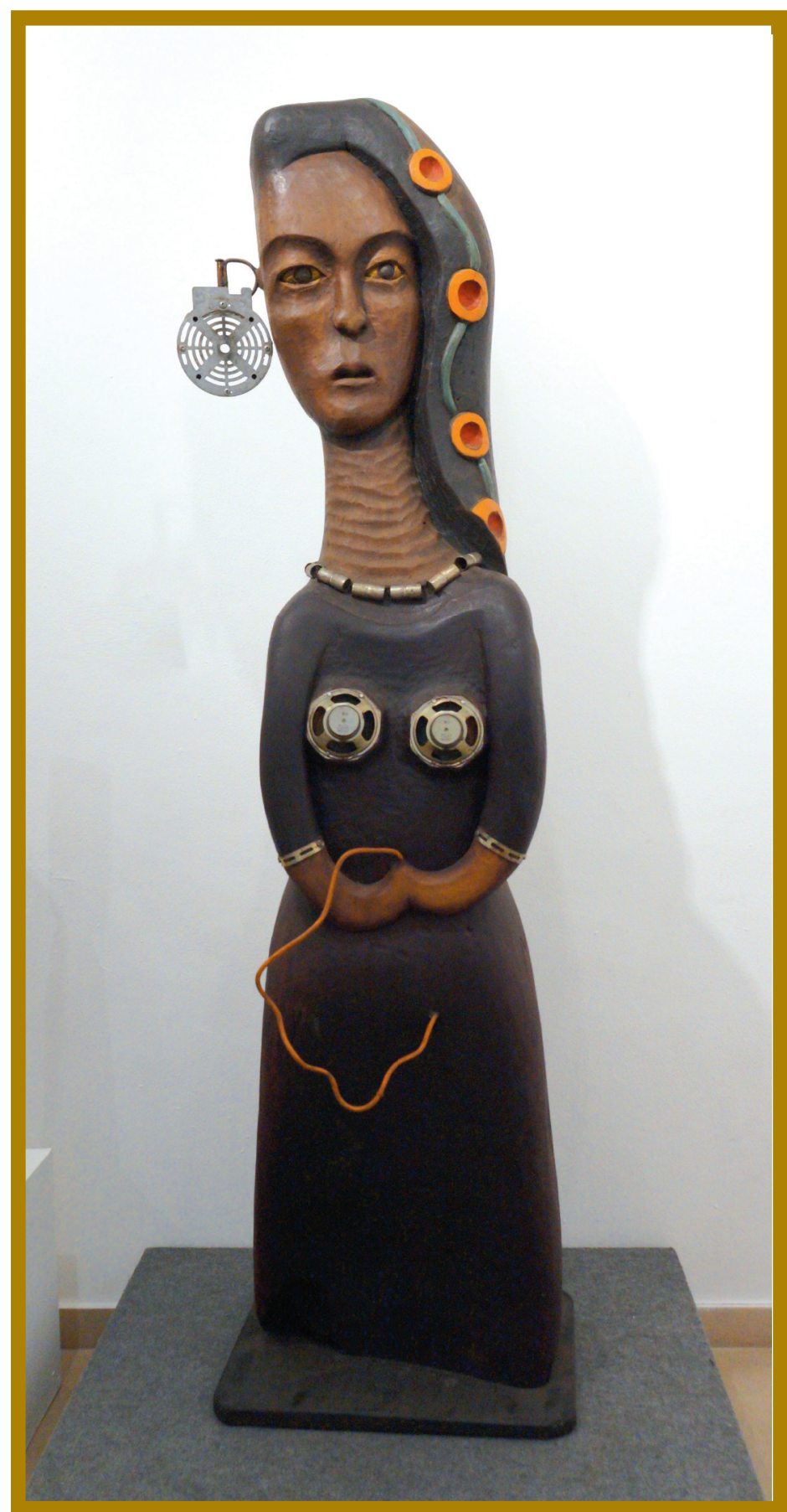

Título: La madona de Monimbó

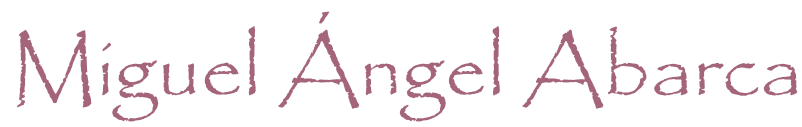

Escultores magníficos son aquellos que logran dotar a la materia, sea esta mármol, piedra, madera o metales, de una capacidad de expresión estética que contenga las dimensiones de una realidad y/o de una suprarrealidad. Un artista excepcional en su creatividad de formas y en su férrea voluntad de dominio sobre los materiales, es el Maestro Miguel Ángel Abarca. Discurriendo en las vetas de la madera, en los estratos del mármol o la piedra, erizando los vértices del hierro, el Maestro Abarca logra captar el dolor, el sueño, la sorpresa, el bostezo, la virginidad, la vegetabilidad o la muerte. Manos y mente que logran congelar en materia un gesto, un hecho, un evento, un vuelo.

Pero esta Madona de Monimbó que hemos seleccionado para Pintura Fresca, nos coloca frente un Abarca crítico y contemporáneo que logra plasmar un sincretismo entre una escultura clásica de madera que evoca una inmaculada náhuatl y aparatos eléctricos que aluden a la remoción del aire, se apoderan como metáforas de sonidos (parlantes) de los pechos de la imagen o ciñen su cintura con un alambre conductor de fluidos eléctricos. Una escultura que es una instalación.

Siempre que me enfrento a las múltiples imágenes de nuestro Miguel Ángel Abarca, se me ocurre infinito en su poder creativo y lo siento un ser humano que en 1945 nos regaló Monimbó de Masaya Nicaragua para gloria del arte.

\section{Anastasio Lovo}

Escritor Nicaragüense 